\title{
The safety of spinal manipulative therapy in children under 10 years: a rapid review
}

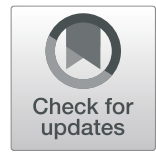

Melissa Corso ${ }^{1}$, Carol Cancelliere ${ }^{1}$, Silvano Mior ${ }^{1,2}$, Anne Taylor-Vaisey ${ }^{1,2}$ and Pierre Côté ${ }^{*}$ (DD

\begin{abstract}
Introduction: The safety of spinal manipulative therapy (SMT) in children is controversial. We were mandated by the College of Chiropractors of British Columbia to review the evidence on this issue.

Objectives: We conducted a rapid review of the safety of SMT in children (<10 years). We aimed to: 1 ) describe adverse events; 2) report the incidence of adverse events; and 3) determine whether SMT increases the risk of adverse events compared to other interventions.

Evidence review: We searched MEDLINE, CINAHL, and Index to Chiropractic Literature from January 1, 1990 to August 1, 2019. We used rapid review methodology recommended by the World Health Organization. Eligible studies (case reports/series, cohort studies and randomized controlled trials) were critically appraised. Studies of high and acceptable methodological quality were included. The lead author extracted data. Data extraction was independently validated by a second reviewer. We conducted a qualitative synthesis of the evidence.
\end{abstract}

Findings: Most adverse events are mild (e.g., increased crying, soreness). One case report describes a severe adverse event (rib fracture in a 21-day-old) and another an indirect harm in a 4-month-old. The incidence of mild adverse events ranges from $0.3 \%$ ( $95 \%$ Cl: $0.06,1.82)$ to $22.22 \%$ (95\% Cl: $6.32,54.74)$. Whether SMT increases the risk of adverse events in children is unknown.

Conclusion: The risk of moderate and severe adverse events is unknown in children treated with SMT. It is unclear whether SMT increases the risk of adverse events in children $<10$ years.

Keywords: Adverse event, Child, Pediatric, Safety, Spinal manipulation, Spinal mobilization

\section{Introduction}

The treatment of children with spinal manipulative therapy (SMT) by chiropractors is controversial [1-3]. A recent study of Ontario chiropractors suggests that $5.5 \%$ of patients who consulted a chiropractor in the previous month are between the ages of 0 and 14 years [4]. A crosssectional survey of 140 chiropractors in Alberta indicates that all respondents treated children between 0 and 18 years of age and $13 \%$ of all visits in the previous month were with children [5]. Worldwide, the estimated 12 month median utilization and interquartile range (IQR) of chiropractic care is $8.1 \%$ (IQR $3.8-20.00$ ), with a lifetime median utilization of $11.1 \%$ (IQR 4.0-21.6) for patients 18 years old or less [6]. Children visit chiropractors for a

\footnotetext{
* Correspondence: pierre.cote@uoit.ca

${ }^{1}$ Faculty of Health Sciences, Centre for Disability Prevention and Rehabilitation, Ontario Tech University and CMCC, 2000 Simcoe St N, Oshawa, ON L1G 0C5, Canada

Full list of author information is available at the end of the article
}

variety of reasons, including health promotion, asthma, otitis media, allergies, infantile colic, tonsillitis, ADHD, and enuresis, but most commonly for musculoskeletal (MSK) problems [6-12].

Although the effectiveness of chiropractic care for the management of pediatric MSK and non-MSK conditions is debatable, most of the controversy surrounds the safety of SMT in children [3, 13]. A survey of Canadian pediatricians suggests that serious adverse events of SMT in children may be rare [14]. Previous systematic reviews identified case reports of serious adverse events of SMT including death and temporary paraplegia [13, 15]. However, these systematic reviews did not assess the methodological quality of the included studies. This is problematic because of the high risk of bias associated with such reports $[16,17]$. Although previous systematic reviews reported on the type and frequency of adverse events, they did not describe the incidence of adverse

(C) The Author(s). 2020 Open Access This article is distributed under the terms of the Creative Commons Attribution 4.0 International License (http://creativecommons.org/licenses/by/4.0/), which permits unrestricted use, distribution, and 
events, or determine whether SMT increases the risk of adverse events compared to other interventions [13, 15, 18]. Therefore, little evidence is available to understand the risk of adverse events associated with SMT in children $[13,15,18]$. There is a need to update these reviews to inform the current policy debate about the safety of SMT in children.

To assist in informing this public debate, the College of Chiropractors of British Columbia called for a review of the evidence on the safety of SMT for children under the age of 10 years [19]. At the request of the College of Chiropractors of British Columbia, we conducted an independent rapid review of observational studies and randomized controlled trials (RCTs) to investigate the type and risk of adverse events in children under the age of 10 years ( $0-9$ years) who receive SMT from any health care provider. Specifically, we aimed to: 1) describe the reported adverse events; 2) report the incidence of adverse events; 3 ) determine whether SMT is associated with an increased risk in adverse events compared to other interventions used to manage children for any health condition, or the promotion of health and wellness.

\section{Methods}

Rapid reviews are used by health decision-makers (clinicians, patients, managers, and policy makers) who need timely access to health information to plan, develop and implement health policies [20,21]. Rapid reviews are a valuable method to provide actionable and relevant evidence to make informed decisions in a short amount of time $[20,21]$. They follow the key principles of knowledge synthesis used in systematic reviews, including clear objectives, a priori definition of eligibility criteria, a systematic search for relevant evidence, assessment of validity of findings and a systematic presentation and synthesis of results [20]. However, certain components of the systematic review process are simplified or narrowed to produce information in a timely manner, such as a focused research question, limited databases searched, and one reviewer for screening, critical appraisal and data extraction using standardized established procedures [21]. We followed the methodology recommended by the World Health Organization [20].

\section{Protocol and registration}

We reported our review according to the PRISMA and PRISMA harms checklists (Additional file 3) [22, 23]. We registered our review with the International Prospective Register of Systematic Reviews (PROSPERO) on August 1, 2019 (CRD42019145581).

\section{Eligibility criteria \\ Participants}

We included studies of children between 0 and 9 years of age [24] who received spinal manipulation or mobilization for the prevention or management of any health condition (i.e., MSK or non-MSK disorders) or for the promotion of health and wellness. We did not restrict our review to studies that reported adverse events, rather we considered any study that focused on the treatment of children between 0 and 9 years old with SMT.

\section{Interventions}

SMT includes spinal manipulation and spinal mobilization provided by any type of provider. Spinal manipulation includes techniques incorporating a high-velocity, lowamplitude impulse or thrust applied at or near the end of a joint's passive range of motion $[25,26]$. Spinal mobilization includes techniques incorporating a low-velocity and varying amplitude oscillatory movement within a joint's passive range of motion [26-28]. Spinal manipulation and mobilization involve manual and mechanically-assisted procedures.

\section{Comparators}

We considered all control interventions tested in cohort studies and RCTs to determine the relative risk of adverse events. This may include, but are not limited to placebo, sham manual therapies, wait listing, usual care, no interventions, medication and other manual therapies.

\section{Outcomes}

We investigated adverse events including indirect harms (Table 1). We defined adverse events as any unfavorable sign, symptom, or disease temporally associated with the treatment, whether or not caused by the treatment [29]. We used predefined categories to rate them as mild, moderate, severe or serious [29]. We also considered indirect harms, where the use of an intervention delays a diagnosis or treatment, and such delay holds a potential harm [14]. We used the classification adapted by a multi-disciplinary team of content experts and providers of SMT [29]. We critically appraised studies reporting on adverse events and then classified the severity and nature of all reported adverse events according to the definitions provided in Table 1 . To be eligible for inclusion, case reports and case series had to describe that the presence (or absence) of adverse events was investigated.

\section{Study designs}

Eligible study designs included: case report, case series, case-control study, cohort study or RCT. We used case reports, case series, case-control studies, cohort studies and RCTs to describe the adverse events reported in the literature (aim 1). We used cohort studies and RCTs to determine the incidence of adverse events associated with SMT (aim 2), and to determine the relative risk of adverse events associated with SMT compared to other interventions (aim 3). 
Table 1 Classification of adverse events [14, 29]

\begin{tabular}{ll}
\hline Mild & Asymptomatic or mild symptoms, requiring self-care only to alleviate symptoms (e.g. ice/heat, over-the-counter analgesic). \\
Moderate & Limiting age-appropriate activities of daily living (e.g. work, school) OR sought care from a medical doctor. \\
Severe & $\begin{array}{l}\text { Medically significant but not immediately life-threatening; temporarily limits self-care (e.g. bathing, dressing, eating); OR urgent or } \\
\text { emergency room assessment sought. }\end{array}$ \\
Serious & $\begin{array}{l}\text { Results in death OR a life-threatening adverse event OR an adverse event resulting in inpatient hospitalization or prolongation of } \\
\text { existing hospitalization for more than } 24 \mathrm{~h} \text {; a persistent or significant incapacity or substantial disruption of the ability to conduct } \\
\text { normal life functions. }\end{array}$ \\
Indirect harms & The use of intervention may cause a delay in diagnosis or treatment and the delay itself carries the potential harm.
\end{tabular}

We excluded guidelines, letters, editorials, commentaries, unpublished manuscripts, dissertations, government reports, books and book chapters, conference proceedings, meeting abstracts, lectures and addresses, consensus development statements, guideline statements, cadaveric, laboratory or animal studies, qualitative studies, systematic reviews and meta-analyses.

\section{Information sources}

We developed our search strategy in consultation with a health sciences librarian, and a second librarian reviewed the strategy to ensure accuracy. We systematically searched three databases that thoroughly index the manual therapy literature published by various health professions from January 1 , 1990 to August 1, 2019: MEDLINE (U.S. National Library of Medicine, through Ovid Technologies Inc.), Cumulative Index to Nursing and Allied Health (CINAHL, through EBSCOhost), and Index to Chiropractic Literature (ICL, Chiropractic Library Collaboration). Search terms consisted of subject headings specific to each database (e.g., MeSH in MEDLINE) and free text words relevant to our objectives and study design [see Additional file 1]. We restricted our search to papers published in English.

\section{Study selection}

We used a two-phase screening process to identify eligible studies. In phase one screening, we reviewed titles and abstracts and classified articles as relevant, possibly relevant or irrelevant. During phase two screening, we reviewed the full text of possibly relevant articles for final determination of eligibility.

A trained investigator (MC) conducted all of the screening. Prior to phase one screening, we validated the quality of screening by MC. Ten percent of all eligible articles were randomly selected and the titles and abstracts of these articles were screened independently by a second experienced investigator (PC). A 95\% level of agreement was required between two reviewers before moving to full phase one screening. Once the $95 \%$ agreement was achieved, one reviewer $(\mathrm{MC})$ completed phase one and two screening.

\section{Risk of Bias in individual studies}

The lead author (MC) critically appraised the internal validity of relevant articles using the Scottish
Intercollegiate Guidelines Network (SIGN) criteria for RCTs, cohort studies and case-control studies [30, 31]. The SIGN methodology provides the reviewer with a list of standardized criteria to determine the risk of bias related to selection bias, measurement bias and confounding. When evaluating an RCT, the reviewer assessed methods of randomization, concealment, blinding, comparability of baseline characteristics, contamination, outcome measurement, loss to follow-up, intention-to-treat and between site differences (for multi-center RCTs). In cohort studies, the items focus on the source population, participation rate, drop-out rate, outcome measurement, blinding, exposure measurement, confounders and statistical analysis. We did not identify any case-control studies; thus, we do not describe the SIGN criteria for this study type.

There are no SIGN criteria for case reports or case studies. Therefore, we adapted the critical appraisal tool proposed by Murad et al. to assess the quality of case reports and case series. We modified the tool by creating a series of critical appraisal criteria and notes similar to the SIGN criteria [see Additional file 2] [17]. The adapted Murad tool allowed us to critically appraise patient selection, exposure and outcome measurement, alternative causes, challenge-rechallenge phenomenon, dose-response, and length of follow-up.

We also included a quality control step in the critical appraisal of studies. The investigator who assessed the risk of bias of the studies (MC) presented a summary of the critically appraised papers to three experienced methodologists (PC, SM, CC) who validated the outcome of the appraisals. Disagreements regarding the internal validity of papers were resolved through discussion. We restricted our synthesis to studies agreed judged to have a low risk of bias. The lead author created risk of bias tables for all eligible studies (including low and high risk of bias studies), which were validated by the other investigators (PC, SM, CC). Studies were rated as high quality, acceptable, low quality or unacceptable.

\section{Data items}

Information extracted from each RCT included participant characteristics (age, indications for treatment or condition treated, and location); sample size; type and 
description of intervention; type and description of comparison group; follow-up period; method of outcome ascertainment; and number and description of adverse events. Information extracted from each cohort study included source population; sample size; participant characteristics (age, indications for treatment or condition treated); exposure/description of intervention; method of outcome ascertainment; confounders; follow-up period; and number and description of adverse events. Information extracted from case reports and case series included participant characteristics (age, indications for treatment or condition treated); type and description of intervention; method of outcome ascertainment; follow-up period; and number and description of adverse events.

\section{Data extraction}

The lead author (MC) extracted data from high and acceptable quality studies and built evidence tables stratified by research objective (Tables 2, 3, 4 and 5). Data extraction was validated by one of three reviewers (PC, CC, $\mathrm{SM})$. We contacted the study authors when clarification or additional information/data was necessary to build the evidence tables [32, 33]. Evidence tables summarized the information relevant to each objective and we used this information to create the summary statements. We used the terminology used by authors to describe adverse events when building our evidence table. For example, authors may have labelled adverse events as "side effects" or adverse reactions [34, 35]. We considered these terms were synonymous to adverse events in our synthesis.

\section{Statistical analyses}

When data were available, we computed the incidence (and 95\% confidence intervals) of adverse events and relative risk (and 95\% confidence intervals) from RCTs and cohort studies. Incidence was measured by calculating the number of adverse events in a group divided by the total number of participants in the same group [36]. Relative risk was measured by dividing the incidence of adverse events in the intervention group by the incidence of adverse events in the comparison group [36]. Confidence intervals (CI) were calculated using incidence of adverse events in each group, total number of participants in each group, and $\alpha=0.05$.

\section{Evidence synthesis}

We used best evidence synthesis methodology to synthesize evidence from high and acceptable quality studies [37]. The evidence synthesis provides conclusions based on the best available evidence or may conclude that there is insufficient evidence to make any conclusions [37].

\section{Reporting of outcomes}

For the two RCTs included in our review, we checked the clinical trials registry for evidence of selective reporting of outcomes or protocol changes. Sawyer et al. was not found in the registry, as it was published in 1999. We retrieved the protocol by Miller et al. (\#NCT01513304) which listed a daily crying diary as the primary outcome (no further information about secondary outcomes was provided).

\section{Results \\ Study selection}

Our search retrieved 1812 citations (Fig. 1). We removed 69 duplicates and screened 1743 articles. Interrater agreement for phase 1 screening was $95.4 \%$ between MC and PC. We screened 215 full-text articles (phase 2). Of those, 33 articles met the inclusion criteria and were eligible for critical appraisal. Reasons for exclusion during phase 2 screening were ineligible publication type $(n=24)$, population $\geq 10$ years old $(n=33)$, intervention did not include SMT $(n=43)$, and outcomes did not include adverse events $(n=73)$.

\section{Risk of Bias within studies}

We critically appraised 33 studies. Of those, eight had a low or unacceptable quality and were excluded from the evidence synthesis [38-45]. These included seven case reports or case series, and one cohort study. High risk of bias studies had the following methodological limitations: $1)$ inadequate outcome ascertainment $(n=4)$ and 2$)$ inadequate exposure ascertainment $(n=8)$ (Tables 6, 7 and 8). Twenty-five studies with high or acceptable quality were included in our evidence synthesis [32-35, 46-66]. Nevertheless, these studies had some methodological limitations including inadequate reporting of adverse events measurement (Tables 6, 7 and 8). We contacted authors from two studies to inquire about the measurements of adverse events [32, 33]. Sawyer et al. clarified that events were measured from reports by the chiropractor at each visit. Similarly, Saedt et al. indicated that adverse events were reported by the manual therapist after each treatment, and further defined the various vegetative responses reported as adverse events. For example, hyperextension (of the trunk or cervical spine) is a reaction an infant can make when they feel discomfort and perspiration is a slight sweating reaction of the infant to the intervention.

\section{Study characteristics}

We included two RCTs, [32, 61] one cohort study [33] and 22 case reports/series [34, 35, 46-60, 62-66] (Tables 2, 3, 4 and 5). All spinal manipulations and mobilizations were provided by chiropractors. One RCT tested the effectiveness of spinal mobilization for the management of infants with unexplained persistent crying [61]. The 


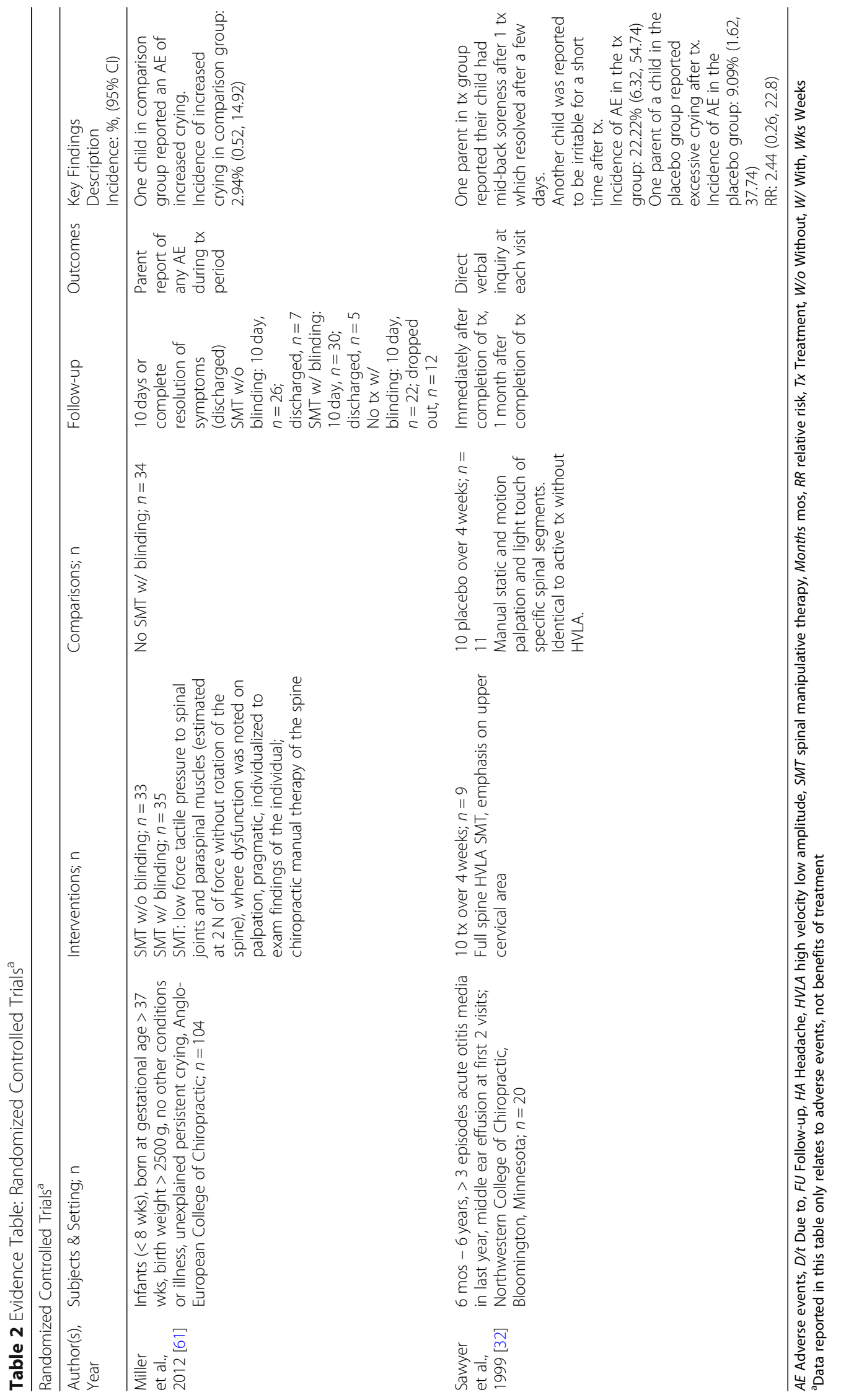


Table 3 Evidence Table: Cohort Studies ${ }^{a}$

\begin{tabular}{|c|c|c|c|c|c|c|}
\hline $\begin{array}{l}\text { Author(s), } \\
\text { Year }\end{array}$ & Source Population & $\begin{array}{l}\text { Sample } \\
\text { Characteristics }\end{array}$ & Exposure & Outcomes & Confounders & Key Findings \\
\hline $\begin{array}{l}\text { Saedt } \\
\text { et al., } \\
2018 \text { [33] }\end{array}$ & $\begin{array}{l}\text { Infants }<27 \text { wks, referred w/ } \\
\text { indications of upper cervical } \\
\text { dysfunction, w/o causative } \\
\text { concomitant pathology, } \\
\text { potential underlying } \\
\text { pathology, \&/or red flags; } \\
\text { Netherlands }\end{array}$ & $\begin{array}{l}\text { Mean age: } 11.2 \text { wks } \\
62.3 \% \text { male } \\
\text { Reasons for seeking } \\
\text { care: clear positional } \\
\text { preference, } \\
\text { restlessness and } \\
\text { abnormal head } \\
\text { position; } n=307\end{array}$ & $\begin{array}{l}\text { Mild mobilization } \\
\text { techniques focusing } \\
\text { on atlas }(\mathrm{C} 1) \text { in } \\
\text { relation to C0-C2. } \\
\text { Average impulse of } \\
11-20 \mathrm{~N} \text {. }\end{array}$ & $\begin{array}{l}\text { Harms recorded by } \\
\text { manual therapists via } \\
\text { questionnaire and } \\
\text { physical exam post-exam: } \\
\text { Mild: transient side effect } \\
\text { lasting < } 24 \mathrm{~h} \\
\text { Moderate: requiring } \\
\text { medical and/or general } \\
\text { practitioner tx } \\
\text { Severe: requiring hospital } \\
\text { tx, AE }\end{array}$ & N/A & $\begin{array}{l}\text { Severe: } 0 \% \\
\text { Moderate: } 0 \% \\
\text { Mild: Vegetative } \\
\text { responses after } \\
\text { mobilization were } \\
\text { reported: } \\
\text { - Flushing: 17.8\% } \\
\text { (14.03, 22.59) } \\
\text { - Hyper-extension: } \\
\text { 4.3\% (2.49, 7.11) } \\
\text { - Perspiration: } \\
\text { 3.6\% (2.01, 6.30) } \\
\text { - Gastro-esophageal } \\
\text { reflux: 0.3\% } \\
\text { (0.06, 1.82) } \\
\text { Short breathing } \\
\text { pattern changes: } \\
\text { 9.2\% (6.39, 12.87) }\end{array}$ \\
\hline
\end{tabular}

AE Adverse events, D/t Due to, FU Follow-up, HA Headache, HVLA high velocity low amplitude, SMT spinal manipulative therapy, Months mos, N/A not applicable, $R R$ relative risk, $T x$ Treatment, W/o Without, $W /$ With, Wks Weeks

${ }^{a}$ Data reported in this table only relates to adverse events, not benefits of treatment

second RCT investigated the effectiveness of high-velocity, low-amplitude SMT for the management of children with acute otitis media [32]. In the cohort study, spinal mobilization was used to treat infants with upper cervical dysfunction [33]. In five case reports or case series the intervention was spinal mobilization, [34, 53, 55, 62, 66] seven provided instrument-assisted SMT, [35, 47, 48, 56, $58,60,65]$ and ten provided high-velocity, low-amplitude SMT modified for the age and development of the patient $[46,49-52,54,57,59,63,64]$.

\section{Description of adverse events}

Adverse events were described in five studies; with one study describing a severe adverse event (case report), one describing an indirect harm (case report), and three studies describing mild adverse events (one RCT, one cohort study, one case series).

Regarding the severe adverse event, acute fractures of the posterior 7th and 8th ribs occurred in a 21-day-old female treated for fussiness and colic, after the use of a spring-activated device on the infant's back [48]. An indirect harm occurred in a 4-month-old male who presented to a chiropractor with head tilt. He was treated with spinal manipulation and a diagnosis of congenital spinal cord astrocytoma was delayed. After the second visit, the child was hospitalized and parents reported the child was difficult to arouse from sleep, limp, pallor, moaning, poor feeding and fever [51].

Three studies described mild adverse events. In an RCT of children between the ages of 6 months and 6 years with acute otitis media, one parent reported midback soreness and one reported irritability during a course of 10 treatments of high-velocity, low-amplitude SMT to the cervical region [32]. In a cohort study of infants less than 27 weeks old with indications of upper cervical dysfunction, adverse events reported by the chiropractor included vegetative responses such as flushing, hyper-extension, perspiration, and gastro-esophageal reflux, and short breathing pattern changes after mild mobilization techniques focusing on $\mathrm{C} 1$ [33]. In a case series, four male and female 5 to 8 -week-old infants presenting with colic were treated with cervical and thoracic pediatric SMT. Parents reported adverse events of poor feeding, mild distress, and increased crying [50]. The parent of a 6-week-old female infant reported a head tilt after cervical SMT [50]. A 17-week-old male infant started to cry immediately after pelvic SMT which resolved after a corrective SMT, with no residual complaints [50]. The mother of a 12-week-old female infant reported crying during and following a cervical spine SMT treatment for suboccipital strain [50].

No adverse events associated with SMT were reported in one RCT, [61] six case series [34, 35, 47, 49, 56, 66] and 13 case reports $[46,52-55,57-60,62-65]$.

\section{Incidence of adverse events}

We computed the incidence of adverse events associated with SMT using data from two RCTs and one cohort study (Tables 2, 3, 4 and 5). In a RCT of infants less than 8 weeks old treated for unexplained persistent crying, the incidence of increased crying in the low force SMT group was $0 \%$ compared to $2.94 \%$ (95\% CI: $0.52,14.92$ ) in the no SMT group [61]. In another RCT of children between the ages of 6 months and 6 years old with otitis media, the incidence of mild adverse events (mid-back soreness and irritability) was $22.22 \%$ (95\% CI: 6.32, 54.74) after full spine high-velocity, low-amplitude SMT (focusing on the cervical region) compared to $9.09 \%$ 
Table 4 Evidence Table: Case Series

\begin{tabular}{|c|c|c|c|c|c|}
\hline $\begin{array}{l}\text { Author(s), } \\
\text { Year }\end{array}$ & Subjects \& Setting; n & Intervention(s) & $\begin{array}{l}\text { Method of Measurement of } \\
\mathrm{AE}\end{array}$ & Follow-up & Key Findings ${ }^{a}$ \\
\hline $\begin{array}{l}\text { lyer, } 2017 \\
{[34]}\end{array}$ & $\begin{array}{l}\text { Patient A: 7-month-old; male; } \\
\text { difficulty with constipation } \\
\text { since birth; } \\
\text { Patient B: 7-month-old; male; } \\
\text { constipation since birth; } \\
n=2\end{array}$ & $\begin{array}{l}\text { Gentle acupressure stimulation } \\
\text { on feet, scar tissue } \\
\text { mobilization, gentle } \\
\text { manipulation was applied to } \\
\text { the cervical and lumbar } \\
\text { segments and SI joints, with } \\
\text { the line of drive being } \\
\text { posterior to anterior and } \\
\text { lateral to medial (magnitude of } \\
\text { thrust and force adapted to } \\
\text { patient age and } \\
\text { neuromusculoskeletal } \\
\text { maturity); patient A also had } \\
\text { DNS rehabilitation } \\
\text { Patient A: } 2 x / \text { week, } 5 \text { wks } \\
\text { Patient B: } 2 x / \text { week, } 4 \text { wks }\end{array}$ & Cannot say & $\begin{array}{l}\text { During } \\
\text { course of tx }\end{array}$ & $\begin{array}{l}\text { No adverse reactions were } \\
\text { reported to occur with the } \\
\text { intervention }\end{array}$ \\
\hline $\begin{array}{l}\text { Young, } \\
2017[56]\end{array}$ & $\begin{array}{l}\text { Patient A: } 26-\text {-month-old; } \\
\text { female; crying on waking } \\
\text { complaining of neck pain; } \\
\text { no known previous } \\
\text { accidents or injuries } \\
\text { during play, played in } \\
\text { bouncy house, no } \\
\text { complaints of pain the } \\
\text { day of; pain increased } \\
\text { on 4th day with reduced } \\
\text { range of motion and } \\
\text { torticollis; } \\
\text { Patient B: } 33 \text {-month-old; } \\
\text { male; playing in bouncy } \\
\text { house, no complaint of } \\
\text { pain or injury, awoke next } \\
\text { morning with right-sided } \\
\text { neck pain, } 1 \text { day later } \\
\text { could not turn head to } \\
\text { the right; } \\
n=2\end{array}$ & $\begin{array}{l}\text { Activator } 4 \text { applied at its } \\
\text { lowest force setting, ischemic } \\
\text { compression to trigger points } \\
\text { to patient tolerance, home } \\
\text { since and range of motion } \\
\text { exercises } \\
\text { Patient A: } 1 \text { tx } \\
\text { Patient B: } 4 \text { tx over } 2 \text { weeks, } \\
\text { with } 3 \text { tx including SMT }\end{array}$ & Cannot say & $\begin{array}{l}\text { Patient A: } 1 \\
\text { week and } 3 \\
\text { years later } \\
\text { Patient B: } \\
\text { throughout } \\
\text { care and } 3 \\
\text { years later }\end{array}$ & $\begin{array}{l}\text { No reported adverse } \\
\text { consequences to occur with } \\
\text { the intervention }\end{array}$ \\
\hline $\begin{array}{l}\text { Zhang, } \\
2004 \text { [35] }\end{array}$ & $\begin{array}{l}\text { Children with acute otitis } \\
\text { media }<2 \text { mos, }<10 \text { years } \\
\text { old, no medical tx; } n=20\end{array}$ & $\begin{array}{l}\text { Low force ( } 2-32 \mathrm{oz}) \text {, Toftness } \\
\text { chiropractic adjustment by a } \\
\text { metered hand-held pressure } \\
\text { applicator at the cervical, thor- } \\
\text { acic, lumbar and sacral contact } \\
\text { site; number of adjustments } \\
\text { range from } 3 \text { to } 6\end{array}$ & Cannot say & $\begin{array}{l}\text { During the } \\
\text { study } \\
\text { period }\end{array}$ & $\begin{array}{l}\text { No side effects or } \\
\text { deterioration of clinical } \\
\text { presentations were found to } \\
\text { occur with the intervention }\end{array}$ \\
\hline $\begin{array}{l}\text { Paravicini, } \\
2018 \text { [66] }\end{array}$ & $\begin{array}{l}\text { Male infants; } 4.5-15 \text { mos old; } \\
\text { diagnosed with arthrogenic } \\
\text { newborn torticollis, } \\
\text { radiographs demonstrated } \\
\text { rotational malposition and } \\
\text { translation of atlas on axis in } \\
\text { all cases; unresponsive to } \\
\text { previous conservative tx } \\
\text { methods; } n=6\end{array}$ & $\begin{array}{l}\text { Mobilization under anesthesia } \\
\text { by doctor of chiropractic and } \\
\text { assistant; atlas in full flexion; in } \\
\text { cases of subluxated C1-2 } \\
\text { articulation, a little traction was } \\
\text { added; assistant chiropractor } \\
\text { stabilized shoulders of sedated } \\
\text { patient; line of drive along } \\
\text { almost horizontal joint place } \\
\text { with minimal force and no } \\
\text { impulse }\end{array}$ & Cannot say & $\begin{array}{l}\text { During the } \\
\text { intervention }\end{array}$ & $\begin{array}{l}\text { No AE occurred with the } \\
\text { intervention }\end{array}$ \\
\hline $\begin{array}{l}\text { Alcantara, } \\
2008[47]\end{array}$ & $\begin{array}{l}\text { Patient A: } 21 \text {-month-old; male; } \\
\text { complaint of constipation } \\
\text { since birth; } \\
\text { Patient B: 7-month-old; fe- } \\
\text { male; complaint of constipa- } \\
\text { tion since } 2 \text { mos; } \\
\text { Patient C: } 21 \text {-month-old; female; } \\
\text { encopresis and severe consti- }\end{array}$ & $\begin{array}{l}\text { Patient A: Decreased HVLA } \\
\text { type thrusts; Activator } \\
\text { technique, } 3 \times / \text { week for } 3 \\
\text { weeks, } 2 x / \text { week for } 3 \text { weeks, } \\
1 \text { x/week ( } 2 \text { mos of care); } \\
\text { dietary changes } \\
\text { Patient B: } 2 x / \text { week for } 3 \text { weeks; } \\
\text { Activator }\end{array}$ & Cannot say & $\begin{array}{l}\text { Patient B: 1- } \\
\text { yr FU, nor- } \\
\text { mal bowel } \\
\text { movements } \\
\text { Patient C: 3- } \\
\text { yr FU nor- } \\
\text { mal bowel } \\
\text { movements }\end{array}$ & $\begin{array}{l}\text { Parents did not report any } \\
\text { adverse reactions to occur } \\
\text { with the intervention }\end{array}$ \\
\hline
\end{tabular}


Table 4 Evidence Table: Case Series (Continued)

\begin{tabular}{|c|c|c|c|c|}
\hline $\begin{array}{l}\text { Author(s), } \\
\text { Year }\end{array}$ & Subjects \& Setting; n & Intervention(s) & $\begin{array}{l}\text { Method of Measurement of } \\
A E\end{array}$ & Follow-up \\
\hline $\begin{array}{l}\text { Alcantara, } \\
2010 \text { [49] }\end{array}$ & $\begin{array}{l}\text { Patient A: 7-year-old; male; } \\
\text { ADHD; Adderall, Zoloft taken } \\
\text { during chiropractic care; } \\
\text { Patient } \\
\text { B: 8-year-old; male; no } \\
\text { medications; } \\
n=2\end{array}$ & $\begin{array}{l}\text { Patient A: } 20 \text { visits over } 32 \\
\text { weeks; proEFA supplement } \\
\text { Patient B: } 49 \text { visits over } 24 \\
\text { weeks } \\
\text { HVLA type thrusts: diversified } \\
\text { and Gonstead techniques }\end{array}$ & Cannot say & $\begin{array}{l}\text { During the } \\
\text { course of } \\
\text { care }\end{array}$ \\
\hline $\begin{array}{l}\text { Miller, } \\
2008[50]\end{array}$ & $\begin{array}{l}\text { Retrospective review of } \\
\text { pediatric cases (patients }=781 \text {, } \\
\text { total visits }=1310) ;<3 \text { years } \\
\text { old; } \text { Chiropractic college } \\
\text { teaching clinic; } n=781 \\
\text { (dismissed no treatment }=82 \text { ); } \\
697 \text { treated \& reported } \\
\text { outcomes; total visits }=5242\end{array}$ & $\begin{array}{l}\text { Patients receiving a type of } \\
\text { chiropractic manipulation } \\
\text { provided by interns }(n=697) \\
\text { Full spine pediatric SMT; } n= \\
531 \\
\text { Occipital-sacral decompression; } \\
n=50 \\
\text { Cervical spine pediatric SMT; } \\
n=47 \\
\text { Thoracic spine pediatric SMT; } \\
n=11 \\
\text { Lumbar spine pediatric SMT; } \\
n=2 \\
\text { Pelvic pediatric SMT; } n=17 \\
\text { Other: } n=33\end{array}$ & $\begin{array}{l}\text { Negative side effects were } \\
\text { detected by interpreting } \\
\text { parental comments in the } \\
\text { FU to the previous tx or } \\
\text { same day as tx ( } n=697) \text {. } \\
\text { Defined as any adverse } \\
\text { reaction reported by the } \\
\text { parent. When an adverse } \\
\text { reaction was reported by } \\
\text { the parents, a description } \\
\text { was detailed. } \\
\text { Mild: transient and lasting } \\
<24 \mathrm{~h} \\
\text { Moderate: requiring } \\
\text { medical (general } \\
\text { practitioner) tx } \\
\text { Severe: requiring hospital tx }\end{array}$ & $\begin{array}{l}\text { During the } \\
\text { course of } \\
\text { care }\end{array}$ \\
\hline
\end{tabular}

Key Findings ${ }^{a}$

No AE documented/ reported by patients or parents to occur with the intervention

Male; 8 weeks old; post first cervical spine SMT tx for infant colic; parents called to report infant was not feeding well and was mildly distressed; following day parents report infant was fine and parents resumed care at the clinic

Female; 8 weeks old; post 4 th tx of cervical and thoracic SMT for infant colic; mother called to report infant had been crying since the tx; mother later reported the infant slept better than usual and resumed care at the clinic

Female; 6 weeks old; few hours post first cervical spine SMT tx, parents reported a "head tilt"; infant was examined and presented with full range of motion and no antalgic posture; care continued Female; 7 weeks old; post first cervical spine SMT for infant colic; mother reported infant cried a lot, slept for 2 $h$, then awoke and continued to cry; continued for 3 more visits and selfdischarged; at FU phone call mother reported infant was "doing fine" and did not require more care

Male; 5 weeks old; FU with the parents; reported they would not attend the 7th visit because after the 6th visit of SMT for infant colic the baby was restless and crying for almost $8 \mathrm{~h}$; they did not continue with tx Male; 17 weeks old; reported birth trauma; on 25th visit immediately post pelvic SMT, infant began to crying, mother felt this was a cry of pain; a corrective ilium adjustment was performed by tutor and the baby stopped crying; mother called later that day to report child was fine; mother continued to bring her child for monitoring and care for next several months Female; 12 weeks old; on 
Table 4 Evidence Table: Case Series (Continued)

\begin{tabular}{|c|c|c|c|}
\hline $\begin{array}{l}\text { Author(s), } \\
\text { Year }\end{array}$ & Subjects \& Setting; n Intervention(s) & $\begin{array}{l}\text { Method of Measurement of Follow-up } \\
\mathrm{AE}\end{array}$ & Key Findings ${ }^{a}$ \\
\hline & & & $\begin{array}{l}\text { 11th visit, cervical spine SMT } \\
\text { done for kinematic } \\
\text { imbalance due to } \\
\text { suboccipital strain, infant } \\
\text { cried during tx and } \\
\text { continued to cry after } \\
\text { returning home; FU next } \\
\text { day by phone, mother } \\
\text { reported the infant was } \\
\text { better but wished to stop tx }\end{array}$ \\
\hline
\end{tabular}

AE Adverse events, D/t Due to, FU Follow-up, HA Headache, HVLA high velocity low amplitude, SMT spinal manipulative therapy, Months mos, RR relative risk, Tx Treatment, W/o Without, W/ With, Wks Weeks

${ }^{\text {a }}$ Results reported in this column cannot be used to infer about the risk of adverse events or the effectiveness of SMT

(95\% CI: 1.62, 37.74) in the placebo group (increased crying) [32]. In a cohort study of infants less than 27 weeks old treated for upper cervical dysfunction with mild mobilization techniques of $\mathrm{C} 1$, the incidence of clinician recorded mild adverse events ranged from $0.3 \%$ (gastro-esophageal reflux) to $17.8 \%$ (flushing) [33].

\section{Association between SMT and adverse events}

In one small RCT of children with acute otitis media treated with high-velocity, low-amplitude SMT primarily to the cervical region $\left(n_{S M T}=9 ; n_{\text {placebo }}=11\right)$, the relative risk of mild adverse events associated with SMT compared with placebo was 2.44 (95\% CI: $0.26,22.8)$ [32].

\section{Discussion}

A limited body of evidence of adequate methodological quality is available to describe and quantify the risk of adverse events associated with SMT in children under 10 years of age. Although serious adverse events are reported in the literature, the risk of serious adverse events remains unknown in this population [48, 51]. Most studies report mild and transient adverse events (e.g., increased crying, soreness, irritability). Our review suggests that the risk of mild adverse events ranges from $0.3 \%$ (95\% CI: $0.06,1.82)$ in infants < 27 weeks old treated with mild mobilization of $\mathrm{C} 1$ for upper cervical dysfunction to $22.22 \%$ (95\% CI: 6.32, 54.74) in children aged between 6 months and 6 years treated for otitis media. We observe that the methods used to measure adverse events are of questionable validity and reliability.

Our review improved on the methodology of previous reviews by evaluating the internal validity of case reports and case series. This is important because the quality of these designs is highly variable and therefore even the description of an observation can be biased [67, 68]. In comparison to Vohra et al. [13], our study collected one additional case report published in 2012, which reported rib fractures in a 21-day-old infant [48]; this study was included in other reviews $[15,18]$. Our review did not include 11 of the 13 studies included in the review by Vohra et al. [13]; one case study was in German, four studies (one RCT, one case report and two case series) did not differentiate a population less than 10 years old, and six studies (four case reports and two case series) were published prior to 1990 . In comparison to Todd et al. [15], our review did not include 28 of the 31 studies included in their review. One case report was not in English, seven studies (two RCTs, one cohort study, three case series and one case report) did not distinguish between or include participants less than 10 years old, eight studies (two RCTs, four case series and one case report) did not provide SMT or were unclear whether every participant received SMT, and 12 were systematic or narrative reviews. A number of adverse events in this review were summarized from other systematic or narrative reviews and not directly from the original report in the literature. In comparison to Humphreys et al., [18] our review did not include three case series because one case series did not distinguish participants under the age of 10 years and two case series did not make it clear that the participants were receiving SMT. None of the previously published reviews included the RCT by Miller et al. (2012), which reported no adverse events in the SMT group and one mild adverse event in the comparison group, [61] nor the cohort study by Saedt et al. (2018) that reported multiple mild adverse events [33]. None of these reviews appraised the methodological quality of studies included in their evidence synthesis. Finally, our review improves on the quality of the other systematic reviews because we computed incidence rates and relative risks where possible.

Methodological differences between previous reviews and our review are important to note because variations in methodology can lead to different conclusions [69, 70]. In their review, Vohra et al. report nine serious adverse events and 20 cases of delayed diagnosis associated with SMT [13]. Similarly, the review by Todd et al. reported 15 serious adverse events and 775 mild to moderate adverse events following manual therapy [15]. Our 
Table 5 Evidence Table: Case Reports

\begin{tabular}{|c|c|c|c|c|c|}
\hline $\begin{array}{l}\text { Author(s), } \\
\text { Year }\end{array}$ & Subjects \& Setting; n & Intervention(s) & $\begin{array}{l}\text { Method of Measurement } \\
\text { of } A E\end{array}$ & Follow-up & Key Findings ${ }^{a}$ \\
\hline $\begin{array}{l}\text { Hubbard, } \\
2010 \text { [62] }\end{array}$ & $\begin{array}{l}\text { 7-year-old; female; migraine } \\
\text { HA, mid-back and abdom- } \\
\text { inal pain for previous } 2 \text { mos, } \\
\text { episodic vomiting for inter- } \\
\text { mittently for } 9 \text { mos }\end{array}$ & $\begin{array}{l}\text { 8-week course of low } \\
\text { velocity, low-amplitude ad- } \\
\text { justments, following upper } \\
\text { cervical pediatric protocol; } 7 \\
\text { tx to C1 over } 13 \text { visits. }\end{array}$ & Cannot say & $\begin{array}{l}\text { During } \\
\text { course of tx }\end{array}$ & $\begin{array}{l}\text { No report of adverse } \\
\text { symptoms occurred after } \\
\text { the intervention }\end{array}$ \\
\hline $\begin{array}{l}\text { Muir, } 2012 \\
{[63]}\end{array}$ & $\begin{array}{l}\text { 5-year-old; male; ADHD (no } \\
\text { medication): acting out, } \\
\text { inability to follow } \\
\text { instructions, poor home and } \\
\text { school performance }\end{array}$ & $\begin{array}{l}11 \text { tx over summer, } 2-3 x / \\
\text { week in November (re- } \\
\text { evaluation at } 4 \text { wks, } 2 x / \\
\text { month between December- } \\
\text { May); SMT, soft tissue ther- } \\
\text { apy, and myofascial release } \\
\text { therapy }\end{array}$ & Cannot say & 1 year & No AE were reported \\
\hline $\begin{array}{l}\text { Bourque, } \\
2018[53]\end{array}$ & $\begin{array}{l}\text { 5-month-old; male; fussing, } \\
\text { irritability, crying, grunting, } \\
\text { rigidity, abnormal position } \\
\text { of left arm, } 2 \text { wks of } \\
\text { constipation, breastfeeding } \\
\text { difficulties on right side, } \\
\text { apparent discomfort lying } \\
\text { on stomach; fracture of left } \\
\text { clavicle during birth }\end{array}$ & $\begin{array}{l}\text { 1x/week for } 2 \text { wks, } 2 \text { tx over } \\
2 \text { mos; sacro-occipital tech- } \\
\text { nic for occipital restriction, } \\
\text { Thoracic spine (T2 and T5) } \\
\text { was treated with the "touch } \\
\text { and hold" technique by } \\
\text { holding a specific, light pres- } \\
\text { sure on the fixated } \\
\text { vertebrae. }\end{array}$ & Cannot say & $\begin{array}{l}\text { Patient A: } 5 \\
\text { weeks } \\
\text { Patient B: } 4 \\
\text { weeks }\end{array}$ & $\begin{array}{l}\text { No AE related with the } \\
\text { intervention }\end{array}$ \\
\hline $\begin{array}{l}\text { Berube, } \\
2004[57]\end{array}$ & $\begin{array}{l}\text { 6-day-old; female; symptoms } \\
\text { of digestive disorder that } \\
\text { began at 4-days-old, diffi- }\end{array}$ & $\begin{array}{l}\text { SMT performed with } \\
\text { diversified technique } \\
\text { modified for gestational age }\end{array}$ & Cannot say & Cannot say & $\begin{array}{l}\text { No AE due to chiropractic } \\
\text { manipulation was reported } \\
\text { by the parent }\end{array}$ \\
\hline
\end{tabular}

Dorough, 2.5-year-old; male; speech 2018 [58] delay, difficulty lying prone, unable to lift head up well, crying when pushing up from ground

Martin-

Marcotte, 2018 [59]

21-month-old; female; episodes of constipation for the past 15 mos

McCormick, 15-month-old; male; motor 2018 [60] developmental delay, not able to crawl, pull up to stand, stand alone or walk

Lacroix,

2016 [64]

4-month-old; female; recurrent regurgitation after feeding, averse to being carried, difficult eructation, interrupted sleep, choking and rumination, wheezing during sleep, fussiness, distended stomach, excessive intestinal gas

Makela,

2018 [65]

3-year-old; female; autism spectrum disorder, no verba
Cervical spine modified Gonstead Technique and instrument-assisted SigmaInstrument; 7 visits $1 \times /$ wk., 8 weeks

Modified Diversified

Technique for the child's

age and development; $2 \mathrm{x}$ / after 10 visits, $1 \mathrm{x} /$ month subsequently

Full spine SMT with

Diversified Technique

assisted); $1 \mathrm{x} /$ week for 4 weeks, 1x/every other week for 12 weeks

17 chiropractic adjustments over 20 weeks; craniosacral technique and Diversified adjusting technique (high velocity low amplitude) week, 4 weeks, re-evaluation

(Activator instrument-

\section{Cannot say}

Cannot say or non-verbal communication, off balance when walking, toe-walking $50 \%$ of the time
SMT provided on 11 visits

over 6 weeks; spring-loaded

Cannot say nique; after re-evaluation,

$2 x /$ week with re-evaluation every month (Dec - Mar)
Over the course of treatment

Over the course of treatment

During the course of care

During the course of care
No adverse reactions to tx were reported to occur with the intervention

No adverse reaction to adjustment reported

No adverse reactions were identified or reported to occur with the intervention

No AE were reported to occur with the intervention 
Table 5 Evidence Table: Case Reports (Continued)

\begin{tabular}{|c|c|c|c|c|c|}
\hline $\begin{array}{l}\text { Author(s), } \\
\text { Year }\end{array}$ & Subjects \& Setting; n & Intervention(s) & $\begin{array}{l}\text { Method of Measurement } \\
\text { of } A E\end{array}$ & Follow-up & Key Findings ${ }^{a}$ \\
\hline $\begin{array}{l}\text { Dobson, } \\
1996[46]\end{array}$ & $\begin{array}{l}\text { 5-year-old; male; asthmatic; } \\
\text { seeks care to promote } \\
\text { "normal" \& vitality posture; } \\
\text { ROM limited in extension; } \\
\text { muscle tension cervical } \\
\text { spine; neutral lateral } \\
\text { radiograph revealed an os } \\
\text { odontoideum }\end{array}$ & $\begin{array}{l}3 \times / \text { week for } 4 \text { weeks, } 4 x / \\
\text { week for } 2 \text { weeks, } 1 \times / \text { week } \\
\text { for } 3 \text { years; toggle-recoil } \\
\text { (short lever high velocity, } \\
\text { very low amplitude) adjust- } \\
\text { ment when indicated }\end{array}$ & Cannot say & Cannot say & $\begin{array}{l}\text { No negative effects were } \\
\text { experienced with the } \\
\text { intervention }\end{array}$ \\
\hline $\begin{array}{l}\text { Wilson, } \\
2012[48]\end{array}$ & $\begin{array}{l}\text { 21-day-old; female; reported } \\
\text { to pediatrician w/ concern } \\
\text { of abnormality/ crepitus on } \\
\text { back; presented to } \\
\text { chiropractor due to fussiness } \\
\text { and colic at 16-days-old }\end{array}$ & $\begin{array}{l}\text { Day } 23, \text { follow-up investiga- } \\
\text { tion by child abuse center } \\
\text { with the chiropractor con- } \\
\text { firmed the parents report. } \\
\text { Parents described } \\
\text { chiropractor initially held }\end{array}$ & $\begin{array}{l}\text { Chest radiograph and } \\
\text { investigation by child abuse } \\
\text { center to confirm reports }\end{array}$ & $\begin{array}{l}\text { At } 35 \text { days of } \\
\text { life, evidence } \\
\text { of rib fracture } \\
\text { healing with } \\
\text { no new } \\
\text { fractures }\end{array}$ & $\begin{array}{l}\text { Acute fractures of } 7 \text { th and } \\
\text { 8th posterior ribs }\end{array}$ \\
\hline
\end{tabular}

Shafrir, 1992 4-month-old; male; head tilt First tx: Neck manipulation [51] noted in first week of life attributed to neck trauma during delivery, noted discomfort when placed on abdomen, could not raise head from prone; told would resolve but no improvement in head tilt after 4 months patient upside down by

hips, with hands around

hips and lower ribs. Applied pressure along spine with fingertips. Used a "springactivated device" on back (in same location of fracture), while patient lay prone on the mother's chest including flexion, extension and axial loading and unloading Second tx: parents returned after first response to manipulation, were reassured and infant was provided another neck manipulation
$3 \mathrm{~h}$ post second tx, admitted Immediately to hospital; routine chest after tx radiograph showed enlargement of the spinal canal from C3-T8. MRI of the head and spine showed a mass within the spinal cord, extending into the medulla superiorly and occupying the entire canal from midcervical to the lower thoracic region.

During surgery, thrombosed veins were noted on the dorsum of the enlarged spinal cord, when spinal cord was incised at C6 level, creamy white, viscoelastic tumour tissue exuded spontaneously. No normal cord tissue was identifiable at this level. Cervical and lower thoracic portions of the tumour were easily removed from normalappearing spinal cord tissue. Pathologic examination revealed mostly necrotic tissue, with the lack of inflammatory infiltrates (suggesting acute necrosis, rather than due to a highgrade malignancy), with several areas of low-grade astrocytoma.
After first tx: difficult to arouse him from a nap, he was described as limp, pale and moaning After second tx: immediately postmanipulation was alert, later began to moan and grunt continuously, fed poorly, fever developed.

Three hours after second neck manipulation, he was admitted to the hospital where he was described as listless and fussy, w/ a weak cry.

Early next morning, he had a brief, generalized seizure, followed by "gasping" respirations and cyanosis, requiring tracheal intubation, followed by another $3 \mathrm{~h}$ seizure. Infant was admitted to the intensive care unit while comatose and rarely responsive to painful stimuli. Later, infant opened eyes and had conjugate movements. Infant had flaccid paralysis of both legs and right arm, with some active motion and withdrawal of the left arm. Post-operatively, infant regained motor and sensory function to the T4 level. 18 months later, he had full use of the upper extremities, sensory function at approximately T9 level and some 
Table 5 Evidence Table: Case Reports (Continued)

\begin{tabular}{|c|c|c|c|c|c|}
\hline $\begin{array}{l}\text { Author(s), } \\
\text { Year }\end{array}$ & Subjects \& Setting; n & Intervention(s) & $\begin{array}{l}\text { Method of Measurement } \\
\text { of } A E\end{array}$ & Follow-up & Key Findings ${ }^{a}$ \\
\hline & & & & & $\begin{array}{l}\text { spontaneous but non- } \\
\text { functional motion of the } \\
\text { right leg. } \\
\text { Diagnosis: congenital spinal } \\
\text { cord astrocytoma }\end{array}$ \\
\hline $\begin{array}{l}\text { Humphris, } \\
2014 \text { [52] }\end{array}$ & $\begin{array}{l}\text { 6-month-old; female; left } \\
\text { head rotation and ipsilateral } \\
\text { flattening of her } \\
\text { posterolateral cranium, } \\
\text { frequent regurgitation of } \\
\text { breast milk immediately } \\
\text { after feeding with inability } \\
\text { to feed from the right } \\
\text { breast, unsettled sleep } \\
\text { patterns }\end{array}$ & $\begin{array}{l}3 \text { visits over } 4 \text { months; } \\
\text { Diversified technique with a } \\
\text { light, modified, HVLA } \\
\text { impulse; no other } \\
\text { interventions provided }\end{array}$ & Cannot say & Cannot say & $\begin{array}{l}\text { No AE were reported or } \\
\text { observed to occur with the } \\
\text { intervention }\end{array}$ \\
\hline $\begin{array}{l}\text { Fairest, } 2013 \\
{[54]}\end{array}$ & $\begin{array}{l}\text { 6-week-old; female; left- } \\
\text { sided cranial flattening and } \\
\text { favored left head rotation, } \\
\text { occasional regurgitation of } \\
\text { an entire breastfeed imme- } \\
\text { diately after feeding, groan- } \\
\text { ing when placed prone in } \\
\text { an inclined position, unset- } \\
\text { tled sleep patterns; advised } \\
\text { by GP \& midwife to seek } \\
\text { chiropractic care }\end{array}$ & $\begin{array}{l}1 \mathrm{x} / \text { week, } 10 \text { weeks; } 7 \text { visits } \\
\text { included Diversified } \\
\text { technique (modified HVLA } \\
\text { thrust) to cervical ( } 7 \text { visits) } \\
\text { and sacrum ( } 1 \text { visit) and } \\
\text { Activator to thoracic ( } 2 \\
\text { visits), } 3 \text { visits of no SMT }\end{array}$ & Cannot say & Cannot say & $\begin{array}{l}\text { No AE were observed, nor } \\
\text { reported to occur with the } \\
\text { intervention }\end{array}$ \\
\hline $\begin{array}{l}\text { Gordon, } \\
2011[55]\end{array}$ & $\begin{array}{l}\text { 2-week-old; male; facial and } \\
\text { upper limb postural } \\
\text { asymmetry following a } \\
\text { forceps-assisted vaginal birth } \\
\text { after Caesarean, droopy lip } \\
\text { on the right, right arm as- } \\
\text { sumed waiter's tip posture } \\
\text { at rest }\end{array}$ & $\begin{array}{l}\text { Chiropractic craniosacral } \\
\text { techniques: low-force static } \\
\text { hold adjustments to cervical } \\
\text { and sacral segments; soft tis- } \\
\text { sue therapy to cervical mus- } \\
\text { cles; } 2 \text { x/week for } 2 \text { weeks, } \\
\text { then } 1 \text { x/every other week } \\
\text { for } 12 \text { weeks }\end{array}$ & Cannot say & Cannot say & $\begin{array}{l}\text { No adverse effects of } \\
\text { management were reported }\end{array}$ \\
\hline
\end{tabular}

AE Adverse events, D/t Due to, FU Follow-up, HA Headache, HVLA high velocity low amplitude, SMT spinal manipulative therapy, Months mos, RR relative risk, Tx Treatment, W/o Without, W/ With, Wks Weeks

${ }^{a}$ Results reported in this column cannot be used to infer about the risk of adverse events or the effectiveness of SMT

results differ from the findings of those reviews because we excluded studies of poor methodological quality, and those where the use of SMT was unclear [13, 15]. Moreover, our review is up to date and includes recently published studies. We improved on the methodology of previous reviews $[13,15,18]$ by excluding case reports where the exposure (i.e. SMT) and outcome (i.e. adverse event) were not adequately measured. Serious and severe adverse events following SMT may be inappropriately reported in the literature $[13,15]$ because most included studies that were not designed nor powered to measure these rare events. Therefore, we recommend future epidemiological studies be designed to specifically estimate the incidence of adverse events within well-defined populations of individuals treated with SMT.

Strengths of our study include adhering to PRISMA and PRISMA harms reporting checklists (Additional file $3),[22,23]$ a protocol established prior to completion and registration with PROSPERO, a clear research question, a robust literature search strategy reviewed by two librarians, screening inter-rater reliability comparison, critical appraisal of eligible studies and a review process by senior scientists at each step of the rapid review. We also included all original research study types (RCTs, cohort studies, case-control studies, case series and case reports) to adequately inform each of our research aims and provided a full electronic search strategy for at least one database including limits used, so our search could be repeated [23]. Our study has limitations. We may have missed studies in our search. A recent study demonstrated that searching MEDLINE alone captured 92\% of papers per systematic review regarding adverse effects of surgical interventions but only $65 \%$ of those for nonsurgical similar effects [71]. The authors recommended that for non-surgical interventions, the search filter should include specific and generic adverse events terms and clearly specify the intervention. Consistent with this recommendation, our search filter included specific terms related to adverse events and harms, as well as SMT related terms. We applied this filter to three databases that capture the majority of manual therapy studies, and that also complies with the WHO rapid review 


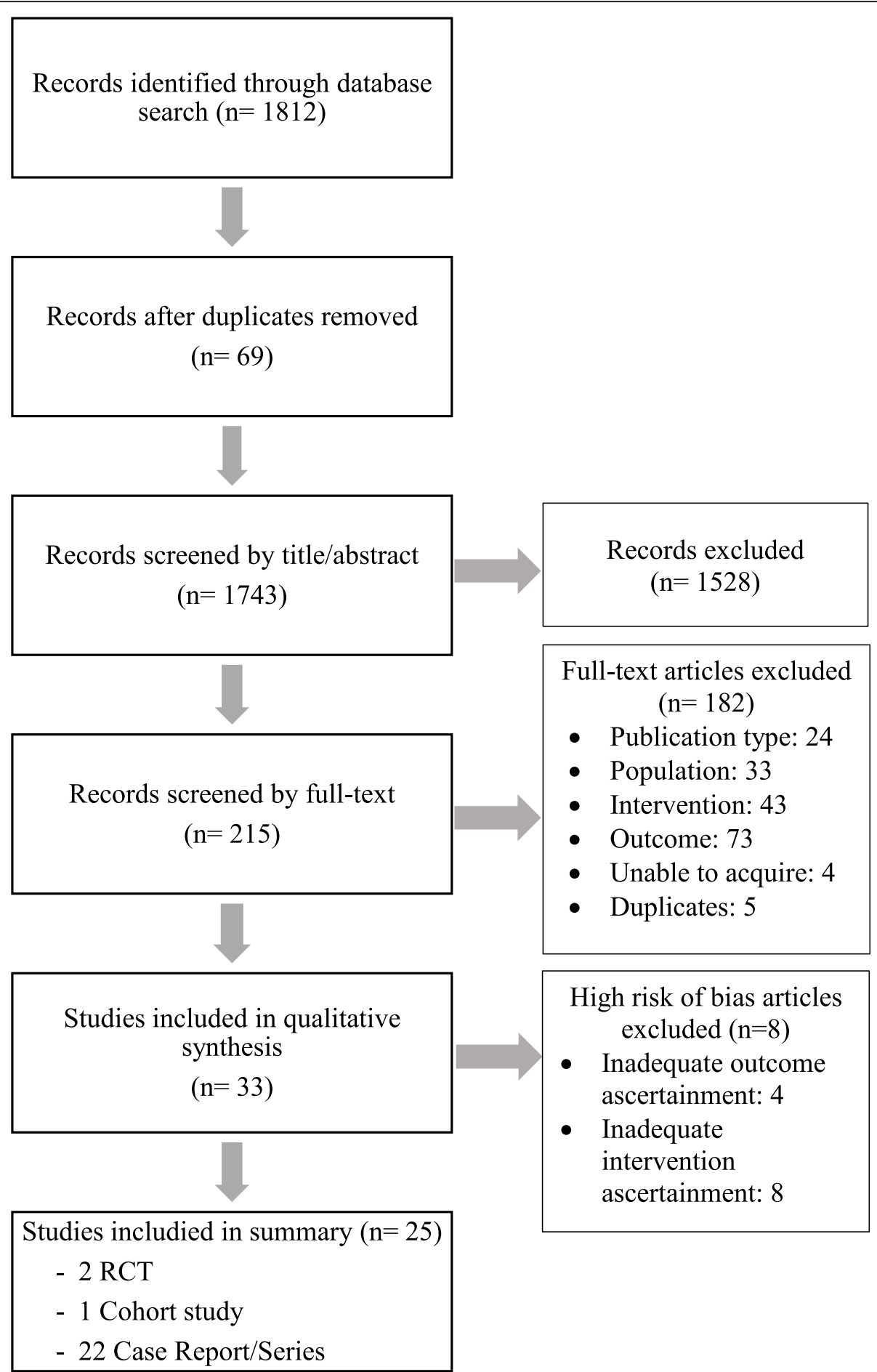

Fig. 1 Flow diagram of study selection

methodology guidelines. We only included studies published in English; however, the majority of studies are published in English [72]. Finally, we only included participants less than 10 years old. While this was specific to our research question, many studies do not categorize participants based on age, which led to a large number of studies being excluded from our review.

On September 30th, 2019, the College of Chiropractors of British Columbia released a public notice reporting on the results of the board regarding SMT treatment 
Table 6 Risk of Bias table: Low risk of bias - RCT

\begin{tabular}{|c|c|c|c|c|c|c|c|c|c|c|c|}
\hline Author, Year & 1.1 & 1.2 & 1.3 & 1.4 & 1.5 & 1.6 & 1.7 & 1.8 & 1.9 & 1.10 & Overall assessment \\
\hline Miller, 2012 [61] & $Y$ & $\bar{Y}$ & $Y$ & $Y$ & Y & Y & CS & $\begin{array}{l}\text { Tx blinded: } 0 \\
\text { Tx not-blinded: } 0 \\
\text { No tx: } 12\end{array}$ & $\bar{Y}$ & $\mathrm{~N} / \mathrm{A}$ & + \\
\hline Sawyer, 1999 [32] & Y & Y & Y & Y & N & Y & CS & $\begin{array}{l}\text { SMT: 0\% (0/9) } \\
\text { Placebo: } 9 \%(1 / 11)\end{array}$ & Y & N/A & + \\
\hline
\end{tabular}

$Y$ yes, $N$ no, N/A not applicable, CS can't say; ++: high quality; +: acceptable quality; -: unacceptable quality/rejected Legend: RCTs

1.1 Research Question

1.2 Method of Randomization

1.3 Concealment

1.4 Blinding

1.5 Baseline Characteristics

1. 6 Contamination

1.7 Outcome Measurement

1.8 Lost to Follow-Up

1.9 Intention-to-Treat

1.10 Between Sites

of children under the age of 10 years [73]. They determined that the treatment of children with SMT does not pose a significant risk to the public and the College of Chiropractors of British Columbia is not pursuing regulatory action at this time [73]. The results of our rapid review were not the only documents reviewed in their analysis. We did not assess the efficacy or effectiveness of SMT for the management of children under the age of 10 years. Therefore, the results of our review cannot be used to make inferences about the risk-benefit ratio of SMT in this population. We recommend that the future development of public and regulatory policies about the use of SMT to treat children include a review of the literature on the efficacy and/or effectiveness of SMT.

Very little is known about the risk of severe and serious adverse events related to SMT in children below the age of 10 years. In one of the few population-based active surveillance studies involving 2500 Canadian pediatricians and pediatric subspecialties, providing coverage to about 7 million children less than 18 years of age, 12 cases of serious adverse events were reported over a two-year period. Of these, eight were adjudicated for risks associated with complementary and alternative medicine use, of which one was possibly related to SMT provided by a chiropractor in a 13-year-old patient. No serious adverse events involving SMT in patients less than 10 years of age were reported [14]. This suggests that these severe and serious adverse events are rare in the general population and studying this issue would require a large sample size. We recommend the implementation of a population-based active surveillance program to measure the incidence of severe and serious

Table 7 Risk of Bias table: Cohort Studies

\begin{tabular}{|c|c|c|c|c|c|c|c|c|c|c|c|c|c|c|c|}
\hline \multicolumn{16}{|c|}{ Risk of Bias table: Low risk of bias - Cohort Studies } \\
\hline Author, Year & 1.1 & 1.2 & 1.3 & 1.4 & 1.5 & 1.6 & 1.7 & 1.8 & 1.9 & 1.10 & 1.11 & 1.12 & 1.13 & 1.14 & Overall Assessment \\
\hline Saedt, 2018 [33] & Y & N/A & Y & N/A & CS & N/A & Y & N/A & CS & CS & N & N/A & N/A & $\mathrm{N}$ & + \\
\hline \multicolumn{16}{|c|}{ Risk of Bias table: High risk of bias - Cohort Studies } \\
\hline Author, Year & 1.1 & 1.2 & 1.3 & 1.4 & 1.5 & 1.6 & 1.7 & 1.8 & 1.9 & 1.10 & 1.11 & 1.12 & 1.13 & 1.14 & Overall Assessment \\
\hline Douglas, 2016 [74] & Y & N/A & $\mathrm{N}$ & N/A & $0 \%$ & N/A & CS & N/A & $\mathrm{N}$ & CS & $\mathrm{N}$ & N/A & N/A & Y & - \\
\hline
\end{tabular}

$Y$ yes, $N$ no, N/A not applicable, CS can't say; ++: high quality; +: acceptable quality; -: unacceptable quality/rejected

Legend: Cohort Studies

1.1 Research Question

1.2 Comparable Sources

$1.3 \%$ Participation

1.4 Outcome Analysis

$1.5 \%$ Drop-out

1.6 Compare Loss to Follow-Up

1.7 Outcome Defined

1.8 Blinding

1.9 Acknowledge Bias

1.10 Reliability of Exposure

1.11 Other Sources for Reliability

1.12 Measurements Occur $>1$ time

1.13 Confounders

1.14 Confidence Intervals 
Table 8 Risk of Bias table: Case Report \& Case Series

\begin{tabular}{|c|c|c|c|c|c|c|c|c|c|}
\hline \multicolumn{10}{|c|}{ Risk of Bias table: Low risk of bias - Case Report \& Case Series } \\
\hline Author, Year & 1.1 & 1.2 & 1.3 & 1.4 & 1.5 & 1.6 & 1.7 & 1.8 & Overall assessment \\
\hline Hubbard, 2010 [62] & CS & Y & CS & $\mathrm{N}$ & N/A & CS & Y & Y & + \\
\hline Muir, 2012 [63] & CS & Y & CS & Y & N/A & CS & Y & Y & + \\
\hline Bourque, 2018 [53] & CS & Y & CS & N & N/A & CS & CS & Y & + \\
\hline lyer, 2017 [34] & CS & Y & CS & Y & N/A & CS & CS & Y & + \\
\hline Young, 2017 [56] & CS & Y & CS & CS & N/A & CS & CS & Y & + \\
\hline Berube, 2004 [57] & CS & Y & CS & Y & N/A & CS & CS & Y & + \\
\hline Dorough, 2018 [58] & CS & Y & CS & N & N/A & CS & CS & Y & + \\
\hline Zhang, 2004 [35] & Y & Y & CS & CS & N/A & CS & CS & $\mathrm{N}$ & + \\
\hline Martin-Marcotte, 2018 [59] & CS & Y & CS & CS & N/A & CS & CS & Y & + \\
\hline McCormick, 2018 [60] & CS & Y & CS & CS & N/A & CS & CS & Y & + \\
\hline Lacroix, 2016 [64] & CS & Y & CS & CS & N/A & CS & CS & Y & + \\
\hline Makela, 2018 [65] & CS & Y & CS & CS & N/A & CS & Y & Y & + \\
\hline Paravicini, 2018 [66] & Y & Y & CS & CS & N/A & CS & Y & Y & + \\
\hline Dobson, 1996 [46] & CS & Y & CS & CS & N/A & CS & CS & Y & + \\
\hline Alcantara, 2008 [47] & CS & Y & CS & CS & N/A & CS & Y & Y & + \\
\hline Wilson, 2012 [48] & CS & Y & Y & Y & N/A & CS & Y & Y & + \\
\hline Alcantara, 2010 [49] & Y & Y & CS & CS & N/A & CS & CS & Y & + \\
\hline Miller, 2008 [50] & Y & Y & Y & Y & N/A & CS & Y & Y & + \\
\hline Shafrir, 1992 [51] & CS & Y & Y & Y & N/A & CS & Y & Y & + \\
\hline Humphris, 2014 [52] & CS & Y & CS & Y & N/A & CS & CS & Y & + \\
\hline Fairest, 2013 [54] & CS & Y & CS & Y & N/A & CS & CS & Y & + \\
\hline Gordon, 2011 [55] & CS & Y & CS & CS & N/A & CS & CS & Y & + \\
\hline \multicolumn{10}{|c|}{ Risk of Bias table: High risk of bias - Case Report \& Case Series } \\
\hline Author, Year & 1.1 & 1.2 & 1.3 & 1.4 & 1.5 & 1.6 & 1.7 & 1.8 & Overall assessment \\
\hline Kinkpe, 2009 [39] & CS & CS & Y & $\mathrm{N}$ & N/A & CS & Y & $\mathrm{N}$ & - \\
\hline Nicolas-Schmid, 2016 [40] & Y & N & Y & CS & N/A & CS & N & N & - \\
\hline Cox, 2016 [41] & Y & $\mathrm{N}$ & CS & CS & N/A & CS & CS & Y & - \\
\hline Miller, 2009 [42] & Y & CS & CS & CS & N/A & CS & CS & Y & - \\
\hline Ghanim, 2019 [43] & CS & $\mathrm{N}$ & Y & Y & N/A & CS & Y & Y & - \\
\hline Deputy, 2014 [44] & CS & CS & Y & N & N/A & CS & Y & Y & - \\
\hline Wiberg, 2010 [45] & $Y$ & CS & CS & CS & N/A & CS & CS & $\mathrm{N}$ & - \\
\hline
\end{tabular}

$Y$ yes, $N$ no, N/A not applicable, CS can't say; ++: high quality; +: acceptable quality; -: unacceptable quality/rejected

Legend: Case report \& case series

1.1 Patient Selection

1.2 Exposure Ascertainment

1.3 Outcome Ascertainment

1.4 Alternative Causes

1.5 Challenge/Rechallenge

1.6 Dose-Response

1.7 Length of Follow-Up

1.8 Sufficient Detail

adverse events following SMT treatment in this population. Research is needed to determine the incidence of adverse events associated with SMT in children. Moreover, future research must improve on the clarity and definition of SMT and use a standardized and valid tool to measure adverse events in children
[14]. Epidemiological studies are also urgently needed to determine whether SMT is associated with an increased risk of severe and serious adverse events. Due to their rarity, it is unlikely that a large enough number of severe and serious adverse events can be captured in RCTs designed to determine the effectiveness of SMT. Therefore, 
we recommend the design and conduct of populationbased case-control (including case-crossover studies), or cohort studies to measure the association between SMT and severe or serious adverse events. It is likely that this type of research can only be done using high-quality population-based administrative databases.

\section{Conclusion}

Most studies report mild and transient adverse events (e.g., increased crying, soreness, irritability) in children under 10 years old receiving SMT. The risk of moderate and severe adverse events is unknown in children treated with SMT. It is unclear whether SMT increases the risk of adverse events in children $<10$ years old. Research is urgently needed to determine the incidence of adverse events associated with SMT in children.

\section{Supplementary information}

Supplementary information accompanies this paper at https://doi.org/10. 1186/s12998-020-0299-y.

Additional file 1: Appendix 1. MEDLINE Search Strategy.

Additional file 2: Appendix 2: Methodology Checklist: Case Report \& Case Series.

Additional file 3: PRISMA

\section{Abbreviations}

Cl: Confidence intervals; MSK: Musculoskeletal; RCT: Randomized controlled trial; SIGN: Scottish Intercollegiate Guidelines Network; SMT: Spinal manipulative therapy

\section{Acknowledgements}

This study was supported by the College of Chiropractors of British Columbia to Ontario Tech University. The College of Chiropractors of British Columbia was not involved in the design, conduct or interpretation of the research that informed the research. This research was undertaken, in part, thanks to funding from the Canada Research Chairs program to Pierre Côté who holds the Canada Research Chair in Disability Prevention and Rehabilitation at Ontario Tech University, and from the Canadian Chiropractic Research Foundation to Carol Cancelliere who holds a Research Chair in Knowledge Translation in the Faculty of Health Sciences at Ontario Tech University.

\section{Authors' contributions}

MC assisted in developing research questions and rapid review methodology, was the main reviewer for article screening, critical appraisal and data extraction, drafted the manuscript, and reviewed and revised the manuscript. PC assisted in developing research questions and rapid review methodology, was the second reviewer for inter-rater reliability of screening phase 1, verified critical appraisal and data extraction, and co-drafted and reviewed the manuscript. CC and SM assisted in developing research questions and rapid review methodology, verified critical appraisal and data extraction, and reviewed and revised the manuscript. ATV assisted in developing research questions and contributed to developing the rapid review methodology, created the systematic database search and reviewed and revised the manuscript. All authors approved the final manuscript as submitted and agree to be accountable for all aspects of the work.

\section{Funding}

This study was supported by the College of Chiropractors of British Columbia to Ontario Tech University. The College of Chiropractors of British Columbia was not involved in the design, conduct or interpretation of the research that informed the research. This research was undertaken, in part, thanks to funding from the Canada Research Chairs program to Pierre Côté who holds the Canada Research Chair in Disability Prevention and Rehabilitation at
Ontario Tech University, and funding from the Canadian Chiropractic Research Foundation to Carol Cancelliere who holds a Research Chair in Knowledge Translation in the Faculty of Health Sciences at Ontario Tech University.

Availability of data and materials

The datasets used and/or analyzed during the current study are available from the corresponding author on reasonable request.

Ethics approval and consent to participate

Not applicable.

Consent for publication

Not applicable.

\section{Competing interests}

Pierre Côté reports research grants unrelated to this work from Aviva Canada, Canadian Institutes of Health Research-Canada Research Chair Program, French Chiropractic Association, Ontario Ministry of Finance, Ontario Trillium Foundation; travel expenditures unrelated to this work from Griffith University - Whiplash Symposium 2017, Southern Denmark University, Institut Franco-Europeen de Chiropraxie, Karolinska Institutet, North American Spine Society, University of Quebec-Trois-Rivieres, University of Zurich, World Federation of Chiropractic; fees medical-legal expertise from the Canadian Chiropractic Protective Association. Carol Cancelliere reports a research grant unrelated to this work from the Canadian Chiropractic Research Foundation - Research Chair in Knowledge Translation in the Faculty of Health Sciences, Ontario Tech University, Canada. Silvano Mior reports research grants unrelated to this work from the Canadian Chiropractic Association, Ontario Chiropractic Association and Ontario Ministry to Seniors Affairs; travel expenditures unrelated to this work from Institut Franco-Europeen de Chiropraxie, World Federation of Chiropractic and University of Norway.

\section{Author details}

${ }^{1}$ Faculty of Health Sciences, Centre for Disability Prevention and Rehabilitation, Ontario Tech University and CMCC, 2000 Simcoe St N, Oshawa, ON L1G 0C5, Canada. ${ }^{2}$ Canadian Memorial Chiropractic College, 6100 Leslie St, Toronto, ON M2H 3J1, Canada.

Received: 15 November 2019 Accepted: 20 January 2020

Published online: 25 February 2020

\section{References}

1. Lindsay B. Chiropractor crackdown: college gives ultimatum on misleading health claims. CBC News: British Columbia. 2018. https://www.cbc.ca/news/ canada/british-columbia/chiropractor-crackdown-college-gives-ultimatumon-misleading-health-claims-1.4861575. Accessed 3 Oct 2019.

2. Lindsay B. Chiropractic treatment for children to face "rigorous" review in B. C. British Columbia: CBC News; 2019. https://www.cbc.ca/news/canada/ british-columbia/chiropractic-treatment-children-bc-review-1.5042864. Accessed 3 Oct 2019

3. Spigelblatt L. Position statement chiropractic care for children: controversies and issues. Can Paediatr Soc Community Paediatr Comm. 2002;7:85-9.

4. Mior S, Wong J, Sutton D, Beliveau PJH, Bussières A, Hogg-Johnson S, et al. Understanding patient profiles and characteristics of current chiropractic practice: a cross-sectional Ontario chiropractic observation and analysis STudy (O-COAST). BMJ Open. 2019;9:e029851.

5. Durant $\mathrm{CL}$, Verhoef MJ, Conway PJ, Sauve RS. Chiropractic treatment of patients younger than 18 years of age: frequency, patterns and chiropractors' beliefs. Paediatr Child Health (Oxford). 2001;6:433-8.

6. Beliveau PJH, Wong JJ, Sutton DA, Ben SN, Bussières AE, Mior SA, et al. The chiropractic profession: a scoping review of utilization rates, reasons for seeking care, patient profiles, and care provided. Chiropr Man Ther. 2017;25:1-17.

7. Siegenthaler M. Pediatric patients in Swiss chiropractic clinics: a questionnaire survey. J Manip Physiol Ther. 2017:40:477-85.

8. Alcantara J, Ohm J, Kunz D. The chiropractic care of children. J Altern Complement Med. 2010;16:621-6.

9. Allen-Unhammer A, Wilson FJH, Hestbaek L. Children and adolescents presenting to chiropractors in Norway: National Health Insurance data and a 
detailed survey. Chiropr Man Ther. 2016;24:1-10. https://doi.org/10.1186/ s12998-016-0107-x

10. Hestbaek L, Jørgensen A, Hartvigsen J. A description of children and adolescents in Danish chiropractic practice: results from a Nationwide survey. J Manip Physiol Ther. 2009;32:607-15. https://doi.org/10.1016/j.jmpt. 2009.08.024.

11. Marchand AM. Chiropractic care of children from birth to adolescence and classification of reported conditions: an internet cross-sectional survey of 956 european chiropractors. J Manip Physiol Ther. 2012;35:372-80. https:/ doi.org/10.1016/j.jmpt.2012.04.008.

12. Pohlman KA, Hondras MA, Long CR, Haan AG. Practice patterns of doctors of chiropractic with a pediatric diplomate: a cross-sectional survey. BMC Complement Altern Med. 2010;10:26.

13. Vohra S, Johnston BC, Cramer K, Humphreys K. Adverse events associated with pediatric spinal manipulation: a systematic review. Pediatrics. 2007;119: e275-83.

14. Zorzela L, Boon H, Mior S, Yager J, Gross A, Vohra S. Serious adverse events associated with pediatric complementary and alternative medicine. Eur J Integr Med. 2014;6:467-72. https://doi.org/10.1016/j.eujim.2014.05.001.

15. Todd AJ, Carroll MT, Robinson A, Mitchell EKL. Adverse events due to chiropractic and other manual therapies for infants and children: a review of the literature. J Manip Physiol Ther. 2015;38:699-712. https://doi.org/10. 1016/j.jmpt.2014.09.008.

16. Gagnier JJ, Kienle G, Altman DG, Moher D, Sox H, Riley D, et al. The CARE guidelines: consensus-based clinical case report guideline development. J Clin Epidemiol. 2014;67:46-51. https://doi.org/10.1016/j.jclinepi.2013.08.003.

17. Murad MH, Sultan S, Haffar S, Bazerbachi F. Methodological quality and synthesis of case series and case reports. BMJ Evid Based Med. 2018;23:60-3.

18. Humphreys BK. Possible adverse events in children treated by manual therapy: a review. Chiropr Osteopat. 2010;18:1-7.

19. Da Roza M. Public notice: review of spinal manipulative therapy in children under the age of 10. College of Chiropractors of British Columbia. 2019. https://www.chirobc.com/public-notice-review-of-spinal-manipulativetherapy-in-children-under-the-age-of-10/. Accessed 3 Oct 2019.

20. Tricco AC, Langlois EV, Straus SE, editors. Rapid Reviews To Strengthen Health Policy And Systems : A Practical Guide. Geneva: World Health Organization; 2017.

21. Tricco AC, Antony J, Zarin W, Strifler L, Ghassemi M, Ivory J, et al. A scoping review of rapid review methods. BMC Med. 2015. https://doi.org/10.1186/ s12916-015-0465-6.

22. Moher D, Liberati A, Tetzlaff J, Altman DG, Group P. Preferred reporting items for systematic reviews and meta-analyses: the PRISMA statement. PLoS Med. 2009;6:e1000097.

23. Zorzela L, Loke YK, loannidis JP, Golder S, Santaguida P, Altman DG, et al. PRISMA harms checklist: improving harms reporting in systematic reviews. BMJ. 2016;352:1157.

24. Definition: Child. World Health Organization. 2019. https://www.who.int/ maternal_child_adolescent/child/en/. Accessed 23 Jul 2019.

25. Definition: Spinal Manipulative Therapy. 2019. http://www.bclaws.ca/ EPLibraries/bclaws_new/document/D/freeside/414_2008. Accessed 23 July 2019.

26. Rubinstein S, Terwee C, Assendelft W, de Boer M, van Tulder M. Spinal manipulative therapy for acute low-back pain. Cochrane Database Syst Rev. 2012;9:CD008880.

27. Dagenais S, Haldeman S. Evidenced-based management of low back pain. Amsterdam: Elsevier; 2012.

28. Maitland G, Hengeveld E, Banks K, English K. Maitlan'd vertebral manipulation. 7th ed. Toronto: Elsevier Butterworth Heinemann; 2005.

29. Pohlman KA, O'Beirne M, Thiel H, Cassidy JD, Mior S, Hurwitz EL, et al. Development and validation of providers' and patients' measurement instruments to evaluate adverse events after spinal manipulation therapy. Eur J Integr Med. 2014;6:451-66.

30. Harbour R, Miller K. A new system for grading recommendations in evidence based quidelines. Br Med J (Clinical Res Ed). 2001;323:334-6.

31. Scottish Intercollegiate Guidelines Network Critical Appraisal: Notes and checklists. 2013. http://www.sign.ac.uk/methodology/checklists.htm/\#. Accessed 1 Oct 2019.

32. Sawyer CE, Evans RL, Boline PD, Branson R, Spicer A. A feasibility study of chiropractic spinal manipulation versus sham spinal manipulation for chronic otitis media with effusion in children. J Manip Physiol Ther. 1999;22: 292-8.
33. Saedt ERIC, Driehuis F, Hoogeboom TJ, Van Der Woude BH, De Bie RA, Der Sanden MWGN. Common manual therapy practices in the Netherlands for infants with upper cervical dysfunction : a prospective cohort study. J Manip Physiol Ther. 2007;41:52-61. https://doi.org/10.1016/j.jmpt.2017.08.003.

34. Iyer MM, Skokos E, Piombo D. Chiropractic management using multimodal therapies on 2 pediatric patients with constipation. J Chiropr Med. 2017;16:340-5.

35. Zhang JQ, Snyder BJ. Effect of the Toftness chiropractic adjustments for children with acute otitis media. J Vertebr Subluxation Res. 2004;2004:4p-p.

36. Fletcher RH, Fletcher SW, Wagner EH. Clinical epidemiology the essentials. Third edit. Baltimore: Williams \& Wilkins; 1996.

37. Slavin R. Best evidence synthesis: an intelligent alternative to meta-analysis. J Clin Epidemiol. 1995;48:9-18.

38. Nicola B, Douglas A, Browning M, Paeds C, Med C, Miller J. Chiropractic care for the cervical spine as a treatment for plagiocephaly: a prospective cohort study. J Clin Chiropr Pediatr. 2016:15:1274-9.

39. Kinkpe CV, Dansokho AV, Coulibaly NF, Niane MM, Seye SI. Sales De gauzy J. fracture of the odontoid process in children: a case report. Orthop Traumatol Surg Res. 2009;95:234-6.

40. Nicolas-Schmid P, Hetlevik MA, Miller J. Infant presentations and outcomes at a chiropractic clinic in the UK: parent report of treatment outcomes using the United Kingdom infant questionnaire (UKIQ). J Clin Chiropr Pediatr. 2016;15:1236-41.

41. Cox J, Davidian C, Mior S. Neck pain in children: a retrospective case series. J Can Chiropr Assoc. 2016;60:212-9.

42. Miller JE, Miller L, Sulesund AK, Yevtushenko A. Contribution of chiropractic therapy to resolving suboptimal breastfeeding: a case series of 114 infants. J Manip Physiol Ther. 2009;21:670-4.

43. Ghanim MT, Bergmann S, Turner RD, Eskandari R, Mahajerin A. Recurrent stroke in a child with Atlantoaxial instability following chiropractic manipulation. J Pediatr Hematol Oncol. 2019;12:12.

44. Deputy SR. Arm weakness in a child following chiropractor manipulation of the neck. Semin Pediatr Neurol. 2014:21:124-6.

45. Wiberg KR, Wiberg JM. A retrospective study of chiropractic treatment of 276 danish infants with infantile colic. J Manip Physiol Ther. 2010;33:536-41.

46. Dobson GJ. Structural changes in the cervical spine following spinal adjustments in a patient with os odontoideum: a case report. J Vertebr Subluxation Res. 1996;1:37-40.

47. Alcantara J, Mayer DM. The successful chiropractic care of pediatric patients with chronic constipation: a case series and selective review of the literature. Clin Chiropr. 2008;11:138-47.

48. Wilson PM, Greiner MV, Duma EM. Posterior rib fractures in a young infant who received chiropractic care. Pediatrics. 2012;130:e1359-62.

49. Alcantara J, Davis J. The chiropractic care of children with attention-deficit/ hyperactivity disorder: a retrospective case series. Explor J Sci Heal. 2010;6:173-82.

50. Miller JE, Benfield K. Adverse effects of spinal manipulative therapy in children younger than 3 years: a retrospective study in a chiropractic teaching clinic. J Manip Physiol Ther. 2008;31:419-23.

51. Shafrir $Y$, Kaufman BA. Quadriplegia after chiropractic manipulation in an infant with congenital torticollis caused by a spinal cord astrocytoma. J Pediatr. 1992;120:266-9.

52. Humphris TJ, Askin A, Glucina-Russell TT. Resolution of non-synostotic plagiocephaly following chiropractic care: a case report. J Clin Chiropr Pediatr. 2014:14:1176-8.

53. Bourque A. Chiropractic management of musculoskeletal disorders associated with a neonatal clavicle fracture: a case report. J Clin Chiropr Pediatr. 2018;17:1449-55.

54. Fairest C. Resolution of birth-related cranial asymmetry following chiropractic care: a case report [case report]. J Clin Chiropr Pediatr. 2013;14:1093-6.

55. Gordon S. Chiropractic management of a combined neonatal brachial plexus and facial nerve palsy: a case report. J Clin Chiropr Pediatr. 2011;12: 879-82.

56. Young MD, Young JL. Conservative Care of Pediatric Acquired Torticollis: A Report of 2 Cases. J Chiropr Med. 2017;16:252-6.

57. Bérubé A-M. Diagnosis and management of a complex milk protein intolerance with chiropractic care: a case report. J Clin Chiropr Pediatr. 2016;15:1253-7.

58. Dorough A. Early intervention: improvement in motor developmental speech delay in a 2-year-old male following chiropractic care: a case report. J Clin Chiropr Pediatr. 2018;17:1444-8.

59. Martin-Marcotte N. Functional constipation in children: which treatment is effective and safe? An evidence-based case report. J Clin Chiropr Pediatr. 2018;17:1485-9 
60. McCormick J, Russell DG. Improvement in motor developmental delay in a 15-month old male following chiropractic care to correct vertebral subluxation: a case report. J Clin Chiropr Pediatr. 2018;17:1405-9.

61. Miller JE, Newell D, Bolton JE. Efficacy of chiropractic manual therapy on infant colic: a pragmatic single-blind, randomized controlled trial. J Manip Physiol Ther. 2012;35:600-7.

62. Hubbard TA, Crisp CA. Cessation of cyclic vomiting in a 7-year-old girl after upper cervical chiropractic care: a case report. J Chiropr Med. 2010;9:179-83.

63. Muir JM. Chiropractic management of a patient with symptoms of attention-deficit/hyperactivity disorder. J Chiropr Med. 2012;11:221-2.

64. Lacroix E. Improvement of gastroesophageal reflux disease (GERD) in an infant following chiropractic care: a case report. J Clin Chiropr Pediatr. 2016; 15:1246-52.

65. Makela SK. Improvements in a three-year-old girl diagnosed with autism spectrum disorder following a trial of chiropractic care: a case report. J Clin Chiropr Pediatr. 2018;17:1480-4.

66. Paravicini I. Manipulation under anesthesia in infants with Arthrogenic newborn torticollis: a retrospective case series. J Chiropr Med. 2018;17:289-97.

67. Kaszkin-Bettag M, Hildebrandt W. Case reports on Cancer therapies: the urgent need to improve the reporting quality. Glob Adv Heal Med. 2012;1:8-10.

68. Kljakovic M. Single cases in general practice and general medical journals. Aust Fam Physician. 2002;31:669-73.

69. Armijo-Olivo S, Da Costa BR, Cummings GG, Ha C, Fuentes J, Saltaji H, et al. PEDro or Cochrane to assess the quality of clinical trials? A metaepidemiological study. PLoS One. 2015;10:1-14.

70. Van Der Velde G, Van Tulder M, Côté P, Hogg-Johnson S, Aker P, Cassidy JD, et al. The sensitivity of review results to methods used to appraise and incorporate trial quality into data synthesis. Spine (Phila Pa 1976). 2007;32: 796-806.

71. Golder S, Wright K, Loke YK. The feasibility of a search filter for the adverse effects of nondrug interventions in MEDLINE and Embase. Res Synth Methods. 2017:8:506-13.

72. Johnson AP, Sikich NJ, Evans G, Evans W, Giacomini M, Glendining M, et al. Health technology assessment: a comprehensive framework for evidencebased recommendations in Ontario. Int J Technol Assess Health Care. 2009: 25:141-50.

73. Da Roza M. Public notice: results of the review of spinal manipulative therapy in children under the age of 10. College of Chiropractors of British Columbia 2019. https://www.chirobc.com/results-of-the-review-of-spinalmanipulative-therapy-in-children-under-the-age-of-10/. Accessed 3 Oct 2019

74. Douglas NA, Browning M, Miller J. Chiropractic care for the cervical spine as a treatment for plagiocephaly: a prospective cohort study. J Clin Chiropr Pediatr. 2016:15:1274-9.

\section{Publisher's Note}

Springer Nature remains neutral with regard to jurisdictional claims in published maps and institutional affiliations.

Ready to submit your research? Choose BMC and benefit from:

- fast, convenient online submission

- thorough peer review by experienced researchers in your field

- rapid publication on acceptance

- support for research data, including large and complex data types

- gold Open Access which fosters wider collaboration and increased citations

- maximum visibility for your research: over $100 \mathrm{M}$ website views per year

At BMC, research is always in progress.

Learn more biomedcentral.com/submissions 